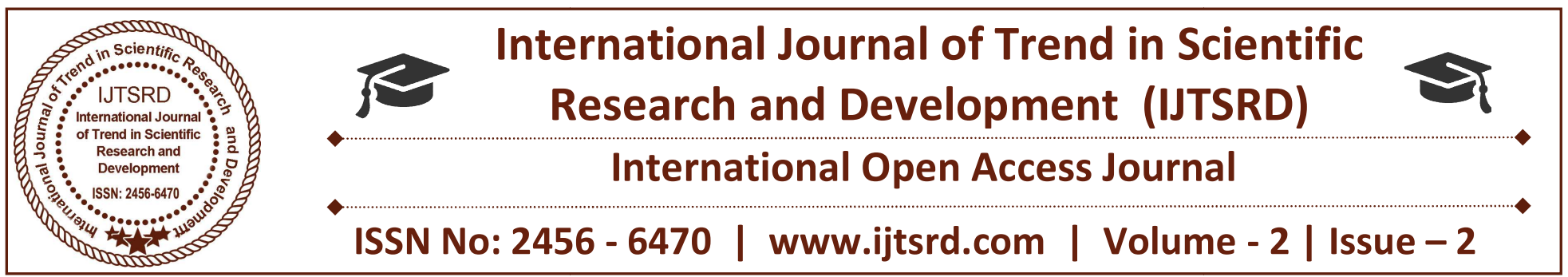

\title{
Growth of Online Marketing: A Special Case study of India
}

\author{
Dr. Pushpa Suryavanshi \\ Assistant Professor, \\ Dr. Hari Singh Gour Central University, \\ Sagar, Madhya Pradesh, India
}

\author{
Prof. Qumar Izhar \\ Professor, Government College, Naigari \\ Rewa, Madhya Pradesh, India
}

\begin{abstract}
Internet is creating a borderless world. The borderless growth maintain the more then emotionally and quickly connection on the world. In this time Internet economy is a global economy in overall world. It requires co-ordination between countries to take advantage of the large opportunities on a global scale. Developing countries are increasingly challenging the traditionally developed nations. The innovation of the Internet has major impact from both technology and business point of view. With the rising trend of Internet use, it is important to ensure that the environment that is being created allows for the strengthening of long term relationship with customers. The number of companies and countries all over the world are using E-Marketing. If India could not meet this challenge, it will suffer the market globalization. It is therefore imperative to understand the structural changes taking place in market and also the long term impact of the changes due to online buying especially to understand the reasons/causes influencing the customers to buy online.
\end{abstract}

Keywords: Borderless, Globalization, E- Marketing, Economy, Internet etc.

\section{INTRODUCTION}

Commerce is a wider area for marketing and social services for the peoples of the world with the help of without wireless and paperless work. In this modern and globalization time every one want innovation and new technology based methods for working. E commerce or electronic commerce gives the more facilities for working in any field. Actually ECommerce is a deal with the buying and selling of goods and services, or transmitting of funds or data over an electronic platform, mainly the internet. This type of business related to the business to business (B2B), business to consumers (B2C), consumer to consumer $(\mathrm{C} 2 \mathrm{C})$, consumer to business $(\mathrm{C} 2 \mathrm{~B})$, and government to consumers $(\mathrm{G} 2 \mathrm{C})$.In this process involved various applications, methods, techniques such as email, fax, Web services, shopping arts, e newsletters to suppliers and etc. for selling and buying.

\section{INTRODUCTION OF INDIA}

India is a country in South Asia. It is the seventh largest country by area, the second most populous country with over 1.2 billion people, and the most populous democracy in the world. Till the date Trend of E-Marketing is continue growing in India, maximum customers are liked the online marking because everyone wants saving of time, money and rush etc. So he likes the online marketing. In India and other countries' maximum companies join the EMarketing for every purpose of self and customers. Growth of online customer continuous rise in the world included India. The current population of India is $1,326,801,576$ (2016) based on the latest Internet Live Stats. India population is equivalent to $17.84 \%$ of the total world population. Second ranks in the list of countries by population but comparatively population 462,124,989 (2016) online users in India. 


\section{OBJECTIVES OF THE STUDY}

1. To study and analysis the internet users of India.

2. To study the E-Marketing growth of India.

3. To study the growth of India comparative with other

countries.

4. To Study the reasons for online Marketing in India.

5. To analysis the better option for improvement of EMarketing in India.

\section{RESEARCH METHODOLOGY}

The study is based on secondary data that has been collected from other secondary sources. The study covers the period of 2010-11 to 2015-16.In the present study, an attempt has been made to growth of E-Marketing in India. These study one related to the Online Marketing sectors.

\section{LIMITATIONS OF THE STUDY}

Due to constraints of time and resources, the study is likely to suffer from certain limitations. The limitations of the study are:

1. The study is based on only secondary sources data.

2. The secondary data are collected from other sources for growth of online marketing in India. 3 . This study based on the only time period 2010-11 to $2015-16$ years.

\section{FOR THIS PURPOSE THJE FOLLOWING PROGRAMME HAVE BEEN STUDIED}

\section{INTERNET USERS OF VARIOUSCOUNTRIES WITH INDIA AS 2016.}

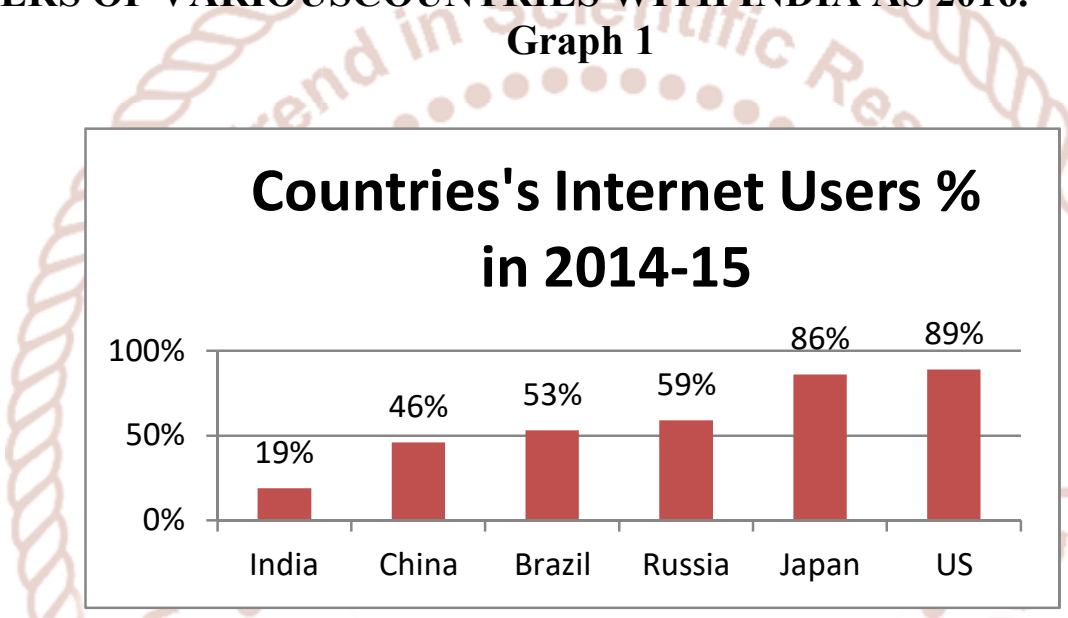

Source: - Market Realist

By observing Graph 1 according to population internet users are increased in per year or day by day in overall world. $89 \%$ internet users in US this is highest condition and lowest condition in India only $19 \%$. If we see the condition of internet users before the time in India, they have grown the uses for online users and E-Marketing.

2. INTERNET USERS IN INDIA 2015-16Geographical distribution of internet users in India

\section{Graph 2 (Million)}

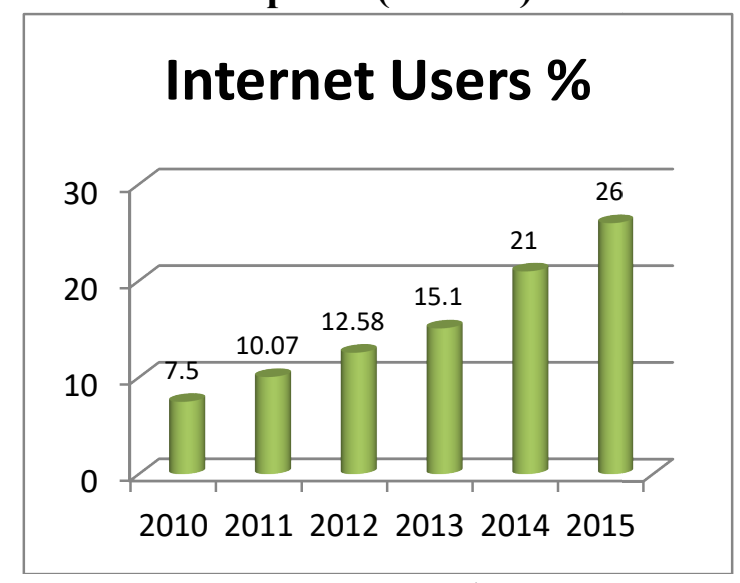

Source: - Google
Graph 3 (Million)

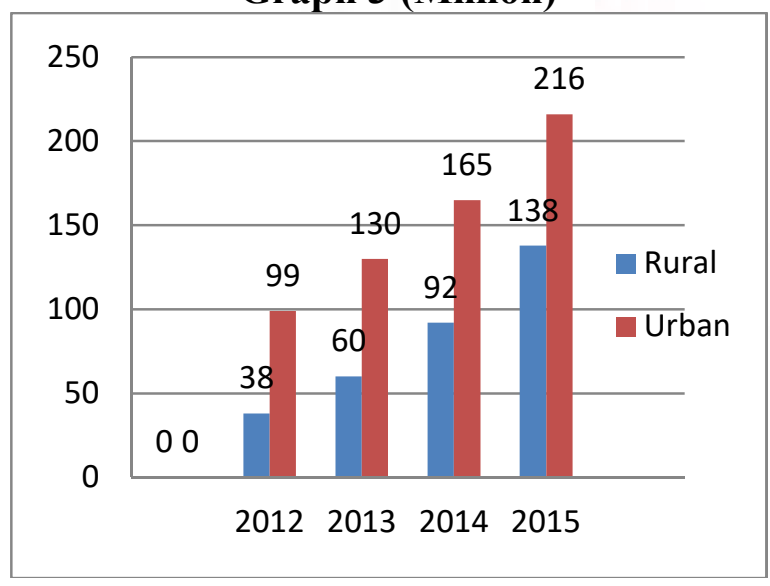

Source: - Google 
By observing and analysis the Graph 2 and 3 in India the internet users are continuously grow per year or day by day for personnel, official and other works. In India internet users year 2010 are $7.5 \%$ and year 2015 the growth of online users are $26 \%$ and till the date the maximum educated and non-educated peoples are use and like the online system process because they know the this system can be save time and avoided the maximum suffering problems. Graph 3 analysis the India's rural and urban online populations. In India rural online user's year 2012 to 2015 increased 100 and urban population year 2012 to 2015 continuously increased 117. These graph show the till the date in India overall rural and urban online users continuously increased.

\section{ONLINE USERS APPLICATIONS OF INDIAINDIAN ONLINE GROWTH}

Graph 4 (Activities performed in India)

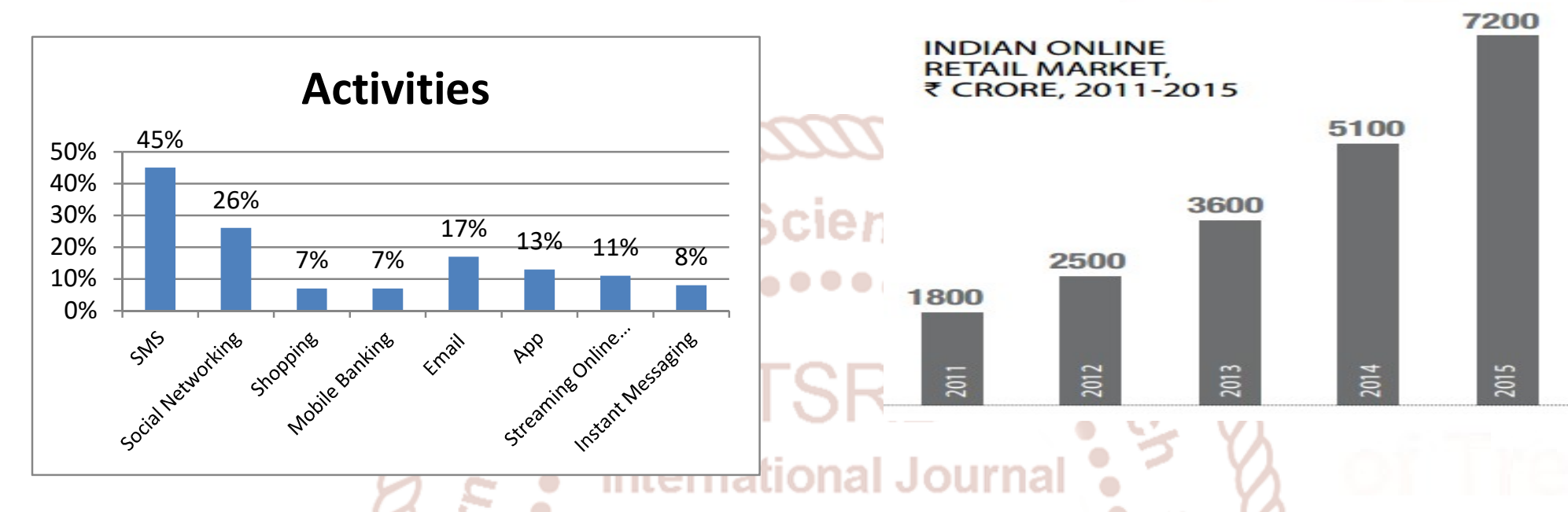

Source: - Mobile Consumer Report, a global snapshot 2013

Graph number 4 shows the various types of activities performed by peoples in India and other countries but in India internet users are like SMS 45\%, Social Networking 26\%, 7\% Shopping, 7\% Mobile Banking, 17\% Email, 13\% App, 11\% Online music, 8\% Instant Messaging etc.with the help of online system. Maximum E- Retail companies' market share \& forecast involve in India like that Snap deal, Mantra, Yebhi, Lets buy, Home shop 18, Naaptol, Flip kart, E Bay and others and Indian online Retail Market growth is year 20111800 Crore and this growth continuously increase year 20157200 Crore.

\section{CHALLENGES OF E -MARKETING IN INDIA}

In India there are many problems for E-Marketing comparatively other countries like that High return rates, cash on delivery, payment gateways inefficiency, a quality penetration, Features phones still rule the roost, Reliable Logistics and Supply Chain, Computer / Internet literacy and effective reach, Tax norms, overfunded competitors are driving up cost of customer acquisition, too many players, startups have to struggle etc. but growth of E-Marketing continuous increase with many problems till the date but mobile, internet, and social media penetration and growth can be quantified, describing the changes in social values and lifestyles that have accompanied those trends is far more challenging.

\section{CONCLUSION}

Online marketing especially search a fastly engine for double digit marketing in few Future years of India and world. In this present time many households used online marketing and growth of online household members continues increased. Maximum E-Marketing companies are foreigner and these companies stable in India. The transaction of online marketing depend on consumers and company, so in this condition the government face the financial loss like that profit, tax etc. This financial loss is own country and own people. The online marketing gives many facilities for all persons of every country in many areas. 


\section{REFERENCES}

1. International Marketing SBPD Publication Writer Dr. S. C. Jain.

2. International Marketing SBPD Publication writer Dr. I. M. Sahai.

3.www.e-marketing in India

4.www.gdp growth of India

5.www.Market Realist

6. Mobile Consumer Report, a global snapshot 7. 